De Jure: Jurnal Hukum dan Syar'iah

Vol. 13, No. 1, 2021, h. 1-13

ISSN (Print): 2085-1618, ISSN (Online): 2528-1658

DOI: http://dx.doi.org/10.18860/j-fsh.v13i1.10913

Available online at http://ejournal.uin-malang.ac.id/index.php/syariah

\title{
The Legal Policy of Judicial Power: The Idea of Implementation of Small Claim Courts in Religious Courts
}

\author{
Imam Sukadi \\ UIN Maulana Malik Ibrahim Malang \\ imam_sukadi@syariah.uin-malang.ac.id \\ Erfaniah Zuhriah \\ UINMaulana Malik Ibrahim Malang \\ erfaniah@yahoo.com
}

\begin{abstract}
:
Religious Court is a judicial environment under the Supreme Court as a perpetrator of judicial power independent of organizing religious court to enforce the law and justice. The implementation of a small claim court in religious courts following simple, quick, and low-cost principles. The Small Claims Court is a simple judicial mechanism outside of the regular judicial mechanisms to resolve disputes quickly and cost lightly. The purpose of this study was to determine the meaning of the principle of fast, simple, and low cost and the legal politics of applying a simple lawsuit in a religious court. This type of research is normative legal research with a statutory approach and a conceptual approach. The technique of analyzing legal materials uses prescriptive. The study results found that the principle of simple, fast, and low cost in religious courts must meet the expectations of justice seekers who always want a speedy, fair, and low-cost trial. Applying the principle of a simple, fast, and low-cost justice has an intrinsic value of justice, inseparable from the service function. The legal politics of implementing a small claims court in a religious court is a breakthrough step, the proceedings are also fast and inexpensive, decided by a single judge, and the trial mechanism is simple So that implementation of Small Claims Court will be able to help the dispute burden in religious courts.
\end{abstract}

Keywords: legal policy; small claim court, religious court.

Abstrak:

Peradilan Agama adalah lingkungan peradilan di bawah Mahkamah Agung sebagai pelaku kekuasaan kehakiman yang mandiri 
menyelenggarakan peradilan agama untuk menegakkan hukum dan keadilan. Penyelenggaraan sidang gugatan kecil di pengadilan agama menganut asas sederhana, cepat, dan murah. Small Claims Court adalah mekanisme peradilan sederhana di luar mekanisme peradilan biasa untuk menyelesaikan sengketa dengan cepat dan biaya ringan. Tujuan penelitian ini adalah untuk mengetahui pengertian asas cepat, sederhana, dan biaya rendah serta politik hukum penerapan gugatan sederhana di pengadilan agama. Jenis penelitian ini adalah penelitian hukum normatif dengan pendekatan perundang-undangan dan pendekatan konseptual. Teknik analisis bahan hukum menggunakan metode preskriptif. Hasil penelitian menemukan bahwa asas sederhana, cepat, dan biaya rendah dalam peradilan agama harus memenuhi harapan para pencari keadilan yang selalu menginginkan peradilan yang cepat, adil, dan berbiaya rendah. Penerapan asas peradilan sederhana, cepat, dan berbiaya rendah memiliki nilai keadilan yang hakiki, tidak terlepas dari fungsi pelayanan. Politik hukum pelaksanaan peradilan gugatan kecil di pengadilan agama merupakan langkah terobosan, proses beracara juga cepat dan murah, diputuskan oleh hakim tunggal, dan mekanisme persidangan sederhana Sehingga pelaksanaan peradilan gugatan kecil akan dapat membantu beban sengketa di pengadilan agama.

Kata Kunci: kebijakan hukum; small claim courts; pengadilan agama.

\section{Pendahuluan}

Etymologically, the term legal policy is from the term Dutch law "rechtpolitikek," which is a form of two words "recht" and "Politiek." Both words contain their meaning so that the words give their understanding. The sense, of course, remains the meaning of its origins. Therefore, to understand the meaning of the legal policy, the word's meaning must first be examined. Namely "Rechtpolitikek" or "legal polcy," which was explained by Hance Van Maarseveen, the legal policy is related to the law of the State.it is explained in his book "Rechtpolitikek, alsopvolger van het Staatrecht". ${ }^{1}$ Padmo Wahjono ${ }^{2}$ said that legal policy is the basic policy that determines the direction, form, and legal content to be formed. Based on the study conducted by Saraswati, public policy was related to government decisions to perform an action that is considered will have an impact for the better with the aim that people's lives also to be better. ${ }^{3}$

The legal policy of the state of Indonesia based on Pancasila intends to develop religious life and religious law in the life of the nation. The theory of "concentric circles" shows how strong the relation between religion, law, and the state. The state based on law and the philosophical of Pancasila protects religious and religious believers, even trying to incorporate religious teachings and religious

\footnotetext{
1 Soimin, Pembentukan peraturan perundang-undangan negara di Indonesia (Yogyakarta: UII Press, 2010), 12.

${ }^{2}$ Padmo Wahjono, Indonesia Negara Berdasarkan Atas Hukum (Jakarta: Ghalia Indonesia, 1983), 160.

3 Putu Sekarwangi Saraswati, "Kebijakan Hukum Terhadap Penanganan Pandemi Covid-19 di Indonesia," KERTHA WICAKSANA 14, no. 2 (July 23, 2020): 147-52, https://doi.org/10.22225/kw.14.2.1923.147-152.
} 
laws in the life of the nation. ${ }^{4}$ Islamic law sourced from the Al-Quran and hadith can be used as a source in legislative products in Indonesia. ${ }^{5}$ Pancasila, as the philosophy of the State, the basis of the State and the fundamental law occupied religious and religious laws in an absolute position. In the national law, the religious law as the form of practice is the first Sila "Ketuhanan Yang Maha Esa" is a legal element and legal material, even the soul and spirit of national law. ${ }^{6}$

This is a fact that Islamic law has become a positive part of Indonesia's law. ${ }^{7}$ The existence of religious justice based on Islamic law is a reflection of Indonesian majority norms as Muslim. Islamic law has become a living law in Indonesian society since Islam began to thrive in the archipelago. The legitimacy of law regulations and jurisprudence, and expert opinions are very influential in Muslim society in Indonesia. From the results of the product, the concept of Al Quran and Al-Hadith as a way of life for Muslims can be applied to the life of nation and state. One example is Law Act Number 7year 1989 on Religious Court, Law Act Number3 year 2006 on amendment of Law Act Number 7 year 1989 on Religious Court, and Law Act Number 50 year 2009 on the Second Amendment of Law Act Number 7 year 1989 on Religious Court. These three laws Act are the existence of Indonesian Islamic law, which has been fortified into the positive law of Indonesia, where the arrangement describes how the duties and authority of the religious court in the case of examining and solving disputes base on Islamic law.

The religious court, which is one of the courts under the Supreme Court, has the duty and authority to examine, solve, and settle the disputes in the first level between the Muslim people in the field of Marriage, heir, testament, Grant, Waqf, Zakat, Infaq, Sadaqah, and the sharia economy as contained in article 49 Law Act Number 3 Year 2006 on amendment of Law Number 7 Year 1989 on the religious court. In carrying out their duties and authorities, the religious court must use simple, fast, and low costs in solving the case. Basically, the public expects the judiciary to adhere to the principles of a good judiciary, especially a trial that can be carried out simply, quickly, and at low cost. ${ }^{8}$ However, every year there are still remaining cases that have not been decided in the religious courts. This condition requires a real solution. ${ }^{9}$

\footnotetext{
${ }^{4}$ Busman Edyar, "Legislasi hukum Islam pada masa pemerintahan Susilo Bambang Yudhoyono (2004-2014)" (Doctoral Thesis, Jakarta, Sekolah Pascasarjana UIN Syarif Hidayatullah Jakarta, 2020), https://repository.uinjkt.ac.id/dspace/handle/123456789/54970.

5 Khairuddin Tahmid, "Legislasi hukum islam persektif tata hukum indonesia," El-Izdiwaj: Indonesian Journal of Civil and Islamic Family Law 1, no. 1 (September 18, 2020), http://ejournal.radenintan.ac.id/index.php/ElIzdiwaj/article/view/7082.

${ }^{6}$ Ach Faisol Triwijaya, Yaris Adhial Fajrin, and Arif Prasetyo Wibowo, "Quo Vadis: Pancasila Sebagai Jiwa Hukum Indonesia," Jurnal Pendidikan PKN (Pancasila dan Kewarganegaraan) 1, no. 2 (November 2, 2020): 115-29, https://doi.org/10.26418/jppkn.v1i2.41083.

${ }^{7}$ Daniel S. Lev, Hukum Dan Politik Di Indonesia :Kesinambungan Dan Perubahan, trans. Nirwono and AE.Priyono (Jakarta: LP3ES, 1990), 121, https://opac.perpusnas.go.id/DetailOpac. aspx?id=448255.

8 Idham Idham, "Gugatan Sederhana (Small Claim Court) Dalam Proses Penyelesaian Sengketa Konsumen Di Indonesia," JUSTICIA SAINS: Jurnal Ilmu Hukum 3, no. 2 (November 30, 2018): 154, https://doi.org/10.24967/jcs.v3i2.364.

9 Direktorat Jenderal Badan Peradilan Agama Mahkamah Agung RI, "Sisa Perkara Agar Menjadi Perhatian," accessed July 14, 2020, https://badilag.mahkamahagung.go.id/seputar-ditjenbadilag/seputar-ditjen-badilag/sisa-perkara-agar-menjadi-perhatian.
} 
The presence of Supreme Court Regulation Number 2 Year 2015 on the of Small Claim Court Procedure Jo Supreme Court Regulation Number 2 Year 2019 on Amendment of Supreme Court Regulation Number 2 Year 2015 about Small Claim Court procedure is a breakthrough to solve the dispute with a simple, quick and low-cost principle. However, this Supreme Court Regulation is only valid in the State Court. In the religious courts, only a matter of sharia economics follows the provisions of Supreme Court Regulation Number 14 Year 2016 on the economic dispute resolution procedures. However, the sharia economic disputes that are submitted to religious court annually are only minimal. Therefore, the small claim court is applied to all types of religious judicial authority to reduce the burden of the disputes.

This type of research is normative legal research. Normative legal research is a process to find the rule of law, legal principles and legal doctrines in order to answer the legal issues faced so that new arguments, theories or concepts are obtained as prescriptions in solving problems. The approach used in a normative legal research will allow a researcher to utilize the findings of empirical law and other sciences for purposes of analysis and legal explanation without changing the character of legal science as a normative science. The research approach used is the statute approach, which is to analyze the rules related to legal issues and the conceptual approach, namely to create a policy concept regarding legal politics, the application of small claim court in religious courts. The types and sources of legal materials consist of primary legal materials, namely legal rules related to research issues, secondary legal materials consisting of books, journals, papers, etc., and tertiary legal materials consisting of legal dictionaries and language dictionaries. The technique of collecting legal materials is by studying legislation and literature studies. The technique of analyzing legal materials using prescriptive analysis.

\section{Result and Discussion}

\section{The Meaning of Quick, Simple, and Low Cost Principle in Religious Court}

The religious court is a judicial environment under the Supreme Court as a perpetrator of judicial power independent of organizing religious judiciary and enforcing law and justice. Religious Court has made Indonesian Muslims settle marital problems, heirs, wills, grants, Waqf, Zakat, Infaq, Sadaqah, and Sharia economics. The civil dispute above occurs when the rights of one party have been reduced or eliminated so that the party who feels aggrieved claims his rights through the intermediary of the judiciary or better known as the litigation route. This will not be a problem when the settlement is concise at less than the material value of the disputed case. However, in reality the settlement of cases sometimes requires a lot of money, so that it can hinder the financial development of the parties involved. ${ }^{10}$

Courts must not only be independent and have integrity, but must be able to provide fair services to all levels of society. For this reason, courts, especially at the first level, must be designed in such a way as to be able to serve the interests of the

\footnotetext{
${ }^{10}$ Kuswandi Kuswandi and Mohammad Nasichin, "Penyelesaian Gugatan Sederhana Dalam Perkara Perdata Di Pengadilan," Jurnal Pro Hukum : Jurnal Penelitian Bidang Hukum Universitas Gresik 8, no. 2 (2019): 237.
} 
community, which is characterized by a low-cost, simple process and fast case settlement time. ${ }^{11}$

According to the provisions of article 2 paragraph (4) of Law Act Number 48 Year 2009 on judicial power, it is stated that "the judiciary is done with simple, quick, and low costs principle." The explanation of article 2 paragraph (4), referred to as "simple," is the examination and settlement of the matter carried out efficiently and effectively."Low cost" means the cost of a matter that the public can reach. It has also been arranged in article 57 paragraph (3) Law Act Number7 year 1989 on the religious court, which reads, "The judiciary is done with simple, quick, and low costs." According to Kamus Besar Bahasa Indonesia, simple means medium (in the middle sense, not high and not low). ${ }^{12}$ Simple refers to the "complicated" or not the settlement of lawsuit. ${ }^{13}$ So, simple principle means clear, easy-to-understand and not-belated way. It is important here that the parties can submit their willing clearly and definitively (unchangeable) and the settlement is clearly, open and definite, with the application of flexible procedure laws in the interest of the parties that want a simple procedure. ${ }^{14}$

Simple in the judicial process is that the judicial procedure must be easy to understand and not convoluted. So the simple intention is that the procedures in the judicial process in the institution of the court should not be convoluted, not too many formalities that will lead to many interpretations. Quick means a short time, in a short time, soon, not much in the procedure (not many stages). ${ }^{15}$ Fast or appropriate referring to "tempo" fast or slow the settlement of the dispute. ${ }^{16}$ The quick point is that in the whole judicial process must be done quickly from the earliest stage to the last stage. The quick principle in the judicial process here means the settlement of the dispute takes less time. The Supreme Court in circular letter Number 1 Year 1992 provides a time limit of six (6) months. It means that each dispute must be resolved within six (6) months from the case that it is registered in the proceeding unless it is subject to legal provisions not to be resolved within six months. Nevertheless, this quickly settlement should run on the right, fair and thorough rule of law. ${ }^{17}$

Six months, in this case, is checked with the regular procedure. It is in different ways with a short procedure and a quick examine procedure applicable in the criminal law and the law of the State Administrative, judicial procedure, while in the civil law (including the law of religious judicial procedure) has not been set. This quick principle is not intended to have the judge examine and solve the divorce case, for example, within an hour or a half-hour. The purpose is a process of examination that is relatively not consuming a long period until years according

${ }^{11}$ Nevey Varida Ariani, "Gugatan Sederhana dalam Sistem Peradilan di Indonesia," Jurnal Penelitian Hukum De Jure 18, no. 3 (September 21, 2018): 382, https://doi.org/10.30641/dejure.2018.V18.381-396.

${ }^{12}$ Kementerian Pendidikan dan Kebudayaan, "Arti Kata Sederhana," accessed March 7, 2021, https://kbbi.kemdikbud.go.id/entri/sederhana.

${ }^{13}$ Setiawan, Aneka masalah hukum dan hukum acara perdata (Bandung: Alumni, 1992), 426.

${ }^{14}$ A. Mukti Arto, Mencari keadilan: kritik dan solusi terhadap praktik peradilan perdata di Indonesia (Yogyakarta: Pustaka Pelajar, 2001), 64.

15 Kementerian Pendidikan dan Kebudayaan, "Arti Kata Cepat," accessed March 7, 2021, https://kbbi.kemdikbud.go.id/entri/cepat.

${ }^{16}$ Setiawan, Aneka masalah hukum dan hukum acara perdata, 427.

${ }^{17}$ Arto, Mencari keadilan, 65. 
to the simplicity of the law procedure itself. ${ }^{18}$ So what is required from the judges in implementing this principle is to conduct a careful and reasonable examination, rational and objective, by giving a balanced and appropriate opportunity to each party.

Secondly, applying this principle should not reduce the accuracy of the examination and judgment according to Law and Justice. For what is the examination process in a fast way if the law asserted therein contains a falsehood and rape of truth and justice, instead of for what righteousness and justice are obtained with misery and bitterness and in a waiting that never comes. Regarding the low cost, cost means the money incurred to hold (establish, do, and so on) something, the cost (administration; fees incurred for mail administration and so on). The cost of dispute settlement administration in a religious court, for example, is for calling the parties the Witness and Stamp. The low cost here refers to the expensive or cheap costs that the Seekers of justice must have in completing their disputes in front of the court. ${ }^{19}$

A low cost, in this case, means no other fees are required unless it is strictly necessary for the completion of the dispute. The costs must be clear and low costs. All payments in the court must be clear and given a receipt of money. The court must respond to the money to the relevant person by noting it in the financial Journal to see it at any time. ${ }^{20}$ The low cost means seeking justice in the courts has done by all societies, not only in certain societies because all of these people are entitled to justice. According to article $121 \mathrm{HIR}$ paragraphs (1) the determination of the cost of the case is done after the lawsuit made is registered by the Registrar in the list provided for it, then the Chairman determines the day and hour, the timing of the cases will be examined in the court. In article 121 (4) HIR specifies "register in the list as referred to in the first paragraph, shall not be done before the plaintiff paid some money to the clerk of court which is temporarily estimated by the Chairman of Court according to the type of case, for the cost of clerks, calling fees and notices required to both parties and stamp rates that will be accounted for. The amount paid will be taken into account. ${ }^{21}$

Meanwhile, according to the instructions from the Directorate General of Islamic Institutional development on the implementation of the Decree of the Minister of Religious Affairs Number 75 year 1979 about the cost of the matter on the subject of religious justice, at the lower left of each decision or Religious courts should include details of the cost of the subject being collected, the point in order to be known by any parties and anyone who need. ${ }^{22}$ The simple, quick, and low-cost principle in religious court must meet the Seekers of Justice's expectations who always want a fast, fair, and low-cost judicial procedure. There is no need for a detailed examination and procedure that can cause the process for up to years; even sometimes, it must be continued by the heirs of justice seekers. The low cost means

\footnotetext{
18 M. Yahya Harahap, Kedudukan, kewenangan, dan acara peradilan agama: UU no. 7 tahun 1989 (Jakarta: Pustaka Kartini, 1990), 71.

${ }^{19}$ Setiawan, Aneka masalah hukum dan hukum acara perdata, 749.

${ }^{20}$ Arto, Mencari keadilan, 67.

${ }^{21}$ Mohammad Taufik Makarao;, Pokok-pokok Hukum Acara Perdata (Rineka Cipta, 2009), 43.

${ }^{22}$ Roihan A. Rasyid, Upaya hukum terhadap putusan peradilan agama (Jakarta: Pedoman Ilmu Jaya, 1989), 35
} 
the lowest possible cost to be accepted in all societies without sacrificing thoroughness to seek truth and justice.

The judiciary's regulation is made on a simple, fast, and low-cost principle basis remains to be held firmly with the legal reflection on the law of civil procedure, which contains regulations on a much simpler examination. The meaning and purpose of judicial principle that is a simple, fast, and low-cost principle to prioritize speed and low-cost procedure, do not mean examining the case done in a complicated way, without thoroughness and accuracy. The implementation of simple, fast, and low-cost judicial principles has the intrinsic value of justice; no matter what the function of service, the judge must truly realize itself as a devoted officer for the sake of law enforcement. Moreover, the judges who serve in the environment of religious courts should be nobler, and more learn the religious predicate. ${ }^{23}$

\section{Policy of Implementation of Small Claim Court in Religious Court}

Moh. Mahfud $\mathrm{MD}^{24}$ said that legal Policy is laws forced or unenforced to reach the goals of the State. Here the law is positioned as a tool for achieving state objectives. Related to this, Sunaryati Hartono has expressed about "the law as a tool" so that practically legal politics is also a tool or a means that the government can use to create a national law to achieve the National ideals and objectives State. ${ }^{25}$ According to Bagir Manan, the legal policy is permanent and temporary. Permanent Legal Policy is related to the nature of the law that will always be the basis of establishment and enforcement policy, while the temporary law is the policy that is set from time to time according to the needs including this category is the determination of priorities for the establishment of local regulations, renewal of legislation that supports national development and so on. ${ }^{26}$ Legal policy regarding the Small Claim Court in religious court is permanent because it will be used as a legal basis for a simple lawsuit that aims to reduce the burden of the subject matter.

Conventionally the settlement of civil disputes (particularly the absolute authority of the religious judiciary) is carried out through a lawsuit-to-justice mechanism (litigation) that often takes a long time to complete one at one level of a religious court. It can be the more extended time it takes if a party applies for a legal effort, appeal, and cassation. This condition is not in line with the principle of fast, simple, and low costs as mandated by the law of judicial power. One of the biggest challenges of the judiciary today is the inefficient settlement of civil cases, especially those related to cases with a small number. Sometimes in small nominal cases, the costs and time spent do not match the amount of money in dispute. This has led to several problems, namely, obstructed public access to settle cases in court, the proliferation of informal debt collectors, which sometimes causes problems, and

\footnotetext{
${ }^{23}$ Harahap, Kedudukan, kewenangan, dan acara peradilan agama, 72.

${ }^{24}$ Moh. Mahfud M. D, Politik hukum di Indonesia (Jakarta: Rajawali Pers, 2011), 1.

${ }^{25}$ Sunaryati Hartono, Politik hukum menuju satu sistem hukum nasional (Bandung: Alumni, 1991), 1.

${ }^{26}$ Zudan Arif Fakrulloh, Ilmu lembaga dan pranata hukum: sebuah pencarian (Jakarta: RajaGrafindo Persada, 2011), 121.
} 
obstacles to the ease of carrying out business activities, especially those categorized as Small and Medium Enterprises (UKM) ${ }^{27}$

The improvement of legal services in the courts is, among other things, in line with the principle that trials are conducted in a simple, fast, and low-cost manner. The existence of a quick event that is used to examine and decide on a simple lawsuit according to the community's needs. ${ }^{28}$ Long and not simple mechanisms are very unfortunate to resolve disputes that require rapid settlement, especially for disputes whose value is small. A civil dispute resolution mechanism is required, which processes fast, simple, and low costs, but the result is judges who have the force of binding law as it is known and developed in developed countries. Its mechanism is known as Small Claims Court, which disputes through courts with a quick and simple procedure. The costs can be lower, using the procedure outside the regular procedure in handling civil litigation. It implemented civil litigation with small claims. Through the mechanism of Small Claims Court, civil dispute resolution is expected to meet the principle of fast, simple low costs. ${ }^{29}$

The Small Claims Court can solve the dispute with a fast procedure, inexpensive cost, and avoid complex and formal litigants. The Small Claims Court is a legal institution intended to provide a fast and economical solution to resolve disputes that do not require an expensive cost. ${ }^{30}$ The Small Claims Court is also interpreted as a "people's court" or a conciliation court for people who desperately need a dispute resolution institution that does not require high fees and is done with a simple process. According to Black Law Dictionary, Small Claims Court means "a court that informally and expeditiouslyadjudicates claims that seek damages below a specified monetary amount, us claims to collect smallaccounts or debtsalso termed smalldebts court; conciliation court." 31 From such a definition, we can understand that the Small Claims Court has several properties, including (a) informally, which can mean a mechanism beyond the general judicial mechanisms; (b) done quickly and efficiently (expeditiously), and (c) compensation claims with a specific monetary amount. $^{32}$

\footnotetext{
27 Benny Riyanto and Hapsari Tunjung Sekartaji, "Pemberdayaan Gugatan Sederhana Perkara Perdata Guna Mewujudkan Penyelenggaraan Peradilan Berdasarkan Asas Sederhana, Cepat Dan Biaya Ringan," Masalah-Masalah Hukum 48, no. 1 (January 30, 2019): 102, https://doi.org/10.14710/mmh.48.1.2019.98-110.

28 Anita Afriana and An An Chandrawulan, "Menakar Penyelesaian Gugatan Sederhana Di Indonesia," Jurnal Bina Mulia Hukum 4, no. 1 (September 13, 2019 ): 57.

${ }^{29}$ Septi Wulan Sari, "Penyelesaian Sengketa Melalui Small Claim Court," Ahkam: Jurnal Hukum Islam $4, \quad$ no. $\quad 2$ (2016): $\quad 328, \quad$ http://ejournal.iaintulungagung.ac.id/index.php/ahkam/article/view/319.

${ }^{30}$ Christopher J. Whelan, Small Claims Courts: A Comparative Study (New York: Oxford University Press, 1990), 7.

${ }^{31}$ Bryan A Garner and Henry Campbell Black, Black's Law Dictionary (St. Paul, MN: Thomson Reuters, 2019).

${ }^{32}$ Yance Arizona, "Small Claim Court: Apa Gunanya Bagi Masyarakat Adat Dan Lingkungan Hidup?," YANCE ARIZONA (blog), October 15, 2010, https://yancearizona.net/2010/10/15/smallclaim-court-apa-gunanya-bagi-masyarakat-adat-dan-lingkungan-hidup/.
} 
The approach and philosophy found in the Small Claims Court are: ${ }^{33}$ (1) The primary responsibility of the Small Claims Court/Tribunal, or in this case, the court is to carry out the justice; (2) Each court is committed to solving the dispute effectively and fairly by upholding the rule of law and improving access to justice; (3) Improving access and accessibility to justice by the community; (4) Maintaining the quality of justice and judicial processes; (5) Facilitate community involvement in the justice process by making them stakeholder of small claims court; (6) Strive to avoid disputes and encourage the reduction in the occurrence of disputes in society. From the explanation above, it is understandable that the Small Claims Court is a simple judicial outside of the regular judicial mechanisms to resolve disputes quickly and at a low cost. The use of the Small Claims Court will help to parse the burden of dispute in court. Of course, not all things can be solved through the Small Claims Court, but only certain matters that meet the criteria can be solved with this Small Claim Court.

In Indonesia, adopting the Small Claims Court is heavily influenced by some cases related to consumer rights. The cases fought by David M. L Tobing related to the rights of consumers with low demands, such as the case of the flight delay of Lion Air with a compensation ruling of $\mathrm{Rp}$. 718,500 and parking management cases that he won with the claim of Rp. 10,000. Moreover, the Supreme Court strengthened the latter case to be jurisprudence and more broadly that any loss of vehicles in the parking lot can be claimed indemnification to parking managers. For Small Claims Court, people who feel harmed or face a case can file a lawsuit without being accompanied by a lawyer. The procedure is also fast and, of course, with a low cost, examined with a single judge, with a simple trial mechanism.

In order to optimize the main tasks of the judiciary to receive, examine, and adjudicate and resolve any disputes submitted to it based on the simple principle of fast and low cost, a legal breakthrough is needed to handle and resolve any disputes or economic cases whose cases have not been resolved even though the case is a simple thing. ${ }^{34}$ The Religious Court is one of the perpetrators of judicial power, which permanently experiences a buildup of cases. Supreme Court Regulation Number 2 Year 2015 on the procedure of settlement of simple lawsuit (Small Claim Court) Jo Supreme Court Regulation Number 2 Year 2019 on amendment of regulation of the Supreme Court number 2 Year 2015 about simple lawsuit and The Supreme Court regulation number 14 Year 2016 on the procedure for solving the sharia economy is the entrance to solve the lawsuit with a small value and voluntary lawsuit (application) in the religious court. Adopting the Small Claims Court with this simple mechanism will reduce the burden of disputes in religious courts, cut complex processes, and make it easier for people to achieve justice by

\footnotetext{
${ }^{33}$ Septi Wulan Sari, "Penyelesaian Sengketa Melalui Small Claim Court," 331.

34 Ayu Rahayu Nurhalizah, "Problematika Gugatan Sederhana Dalam Tinjauan Peraturan Mahkamah Agung Nomor 2 Tahun 2015 Dan Maslahah Mursalah," Journal of Islamic Business Law 4, no. 2 (August 4, 2020): 6.
} 
promoting values of Procedural justice. It means that with the nominal value of small claims and voluntary and the case that the burden of evidence is easy, it should be resolved by a simple judicial mechanism using the Small Claims Court. This follows the justice system in Indonesia, which is organized based on simplicity, speed, and low cost. Simple means not long-winded; fast means that the case examination process is carried out without taking long. ${ }^{35}$

A volunteer case is a letter of application that contains a claim for civil rights by one party with interest in a matter that does not contain a dispute. The judicial body adjudicating can be considered a judicial process that is not actual. ${ }^{36}$ The court issued a decision on this application case. For voluntary courts, in general, the regulations on the law of proof from BW book IV do not apply. Similarly, HIR $(\mathrm{Rbg})$ is generally only provided for contentious courts. According to HIR jurisprudence, the principle of open and open doors and that the decision must contain reasons only applies to contentious courts and not to volunteer courts. ${ }^{37}$

When applying a claim for rights in a civil case, the principle of points d'interest, points d'action, or "no interest, no claim" applies, which means that to file a lawsuit or claim against rights that another party has violated to the court, there must be an interest from the party who proposes to be resolved by the judge in the court following applicable law (positive law), both those containing disputes and those not containing disputes (requests). Volunteer cases are included in the definition of voluntary jurisdiction, and in the case of a request, the judge will determine. ${ }^{38}$

In an application, there are terms applicant and respondent. The person who requests is called the "applicant" or initial request (Dutch) or almudda'y (Arabic). The legal product of the application is istbat (determination) because in the case of the application, there is no opponent (no litigation with other people) the civil court that resolves the petition case is called jurisdictie voluntair (judicial that is not real). It was called so because the court only carried out executive power, not judicial power. ${ }^{39}$ In the meaning of "original," the respondent is not a party. However, it only needs to be presented in front of the court to hear his statement for examination because the respondent has a direct legal relationship with the applicant. So in the original sense, the respondent must not be present in front of the court as the defendant, meaning that even if the respondent is not present if the

\footnotetext{
35 Muhammad Noor, "Penyelesaian Gugatan Sederhana di Pengadilan (Small Claim Court) Berdasarkan Peraturan Mahkamah Agung Nomor 2 Tahun 2015," YUDISIA: Jurnal Pemikiran Hukum dan Hukum Islam 11, no. 1 (June 5, 2020): 54, https://doi.org/10.21043/yudisia.v11i1.6692. ${ }^{36}$ Mardani, Hukum Acara Perdata Peradilan Agama Dan Mahkamah Syar'Iyah (Jakarta: Sinar Grafika, 2010), 80 .

37 Sudikno Mertokusumo, Hukum acara perdata Indonesia (Yogyakarta: Universitas Atma Jaya Yogyakarta, 2010), 1.

${ }^{38}$ Markoni and Elfrida R Gultom, Hukum Acara Perdata (Jakarta: Mitra Wacana Media, 2014), 34.

${ }^{39}$ Mardani, Hukum Acara Perdata Peradilan Agama Dan Mahkamah Syar'Iyah, 81.
} 
applicant is sufficiently grounded (proven), then the applicant will be granted and if it is not proven it will be rejected.

Voluntary cases are cases of application nature, and there are no disputes, so there are no opponents. The petition case cannot be accepted unless the interests of the law so require. Volunteer cases submitted to religious courts include: 1) Determination of guardian guardian for heirs who are unable to take legal action; 2) Appointment of guardian; 3) Determination of adoption; 4) Determination of ratification of marriage (itsbat nikah); 5) Determination of adhol guardians, etc. The legal product of the religious court from the filing of a voluntary case is a determination, not a decision, because, in it, there is no dispute. The main characteristic of this petition case is that the lawsuit is unilateral, and the request and decision are "Declaratoir" (only asking for a declaration of a condition or position). In application cases in which there is no dispute, the settlement mechanism should be simple.

The Simple Lawsuit Mechanism truly applies the principles of simple, fast, and low-cost justice. This can be seen from the mechanism, which shows "simplicity," "speed," and low cost. The principle of simplicity, speed, and low cost in examining and resolving cases in court does not rule out accuracy and precision in seeking truth and justice. If the principle of simple, fast, low cost as described above becomes the spirit of law enforcers, then an effective and efficient judicial system can be realized. ${ }^{40}$ The alignment of Small Claims Court with this simple, fast and low costs principle will become the entrance of society to gain justice. The relevance of Small Claims Court with this simple, fast, and low cost should be thrust for the reformation of the judiciary in religious courts as a new mechanism to settle the case with simplicity.

\section{Conclussion}

The implementation of Small Claim Court in religious courts is a breakthrough to reduce the burden of disputes submitted to religious courts. The concept of a small claim court is aligned with a simple, fast, and low-cost principle. Many of the advantages and benefits of applying this Small Claim Court Procedure, but there needs to be a Supreme Court Regulation that regulates Small Claim Court, is because this regulation is in the incomplete norm. Police of implementation of the Small Claims Court with this simple mechanism will reduce the burden on the accumulation of cases in the religious courts, cut down the complicated legal process, and make it easier for the public to achieve justice.

40 Arman Tjoneng, "Gugatan Sederhana Sebagai Terobosan Mahkamah Agung Dalam Menyelesaikan Penumpukan Perkara Di Pengadilan Dan Permasalahannya," Dialogia Iuridica: Jurnal Hukum Bisnis Dan Investasi 8, no. 2 (June 8, 2017): 105, https://doi.org/10.28932/di.v8i2.726. 


\section{Bibilography}

Afriana, Anita, and An An Chandrawulan. "Menakar Penyelesaian Gugatan Sederhana Di Indonesia." Jurnal Bina Mulia Hukum 4, no. 1 (September 13, 2019): 53-71.

Ariani, Nevey Varida. "Gugatan Sederhana dalam Sistem Peradilan di Indonesia." Jurnal Penelitian Hukum De Jure 18, no. 3 (September 21, 2018): 381-96. https://doi.org/10.30641/dejure.2018.V18.381-396.

Arizona, Yance. "Small Claim Court: Apa Gunanya Bagi Masyarakat Adat Dan Lingkungan Hidup?" YANCE ARIZONA (blog), October 15, 2010. https://yancearizona.net/2010/10/15/small-claim-court-apa-gunanya-bagimasyarakat-adat-dan-lingkungan-hidup/.

Arto, A. Mukti. Mencari keadilan: kritik dan solusi terhadap praktik peradilan perdata di Indonesia. Yogyakarta: Pustaka Pelajar, 2001.

Direktorat Jenderal Badan Peradilan Agama Mahkamah Agung RI. "Sisa Perkara Agar Menjadi Perhatian." Accessed July 14, 2020. https://badilag.mahkamahagung.go.id/seputar-ditjen-badilag/seputarditjen-badilag/sisa-perkara-agar-menjadi-perhatian.

Edyar, Busman. "Legislasi hukum Islam pada masa pemerintahan Susilo Bambang Yudhoyono (2004-2014)." Doctoral Thesis, Sekolah Pascasarjana UIN Syarif Hidayatullah Jakarta, 2020. https://repository.uinjkt.ac.id/dspace/handle/123456789/54970.

Fakrulloh, Zudan Arif. Ilmu lembaga dan pranata hukum: sebuah pencarian. Jakarta: RajaGrafindo Persada, 2011.

Garner, Bryan A, and Henry Campbell Black. Black's Law Dictionary. St. Paul, MN: Thomson Reuters, 2019.

Harahap, M. Yahya. Kedudukan, kewenangan, dan acara peradilan agama: UU no. 7 tahun 1989. Jakarta: Pustaka Kartini, 1990.

Hartono, Sunaryati. Politik hukum menuju satu sistem hukum nasional. Bandung: Alumni, 1991.

Idham, Idham. "Gugatan Sederhana (Small Claim Court) Dalam Proses Penyelesaian Sengketa Konsumen Di Indonesia." JUSTICIA SAINS: Jurnal Ilmu Hukum 3, no. 2 (November 30, 2018): 152-67. https://doi.org/10.24967/jcs.v3i2.364.

Kementerian Pendidikan dan Kebudayaan. "Arti Kata Cepat." Accessed March 7, 2021. https://kbbi.kemdikbud.go.id/entri/cepat.

- "Arti Kata Sederhana." Accessed March 7, 2021. https://kbbi.kemdikbud.go.id/entri/sederhana.

Kuswandi, Kuswandi, and Mohammad Nasichin. "Penyelesaian Gugatan Sederhana Dalam Perkara Perdata Di Pengadilan." Jurnal Pro Hukum: Jurnal Penelitian Bidang Hukum Universitas Gresik 8, no. 2 (2019): 236-61.

Lev, Daniel S. Hukum Dan Politik Di Indonesia:Kesinambungan Dan Perubahan. Translated by Nirwono and AE.Priyono. Jakarta: LP3ES, 1990. https://opac.perpusnas.go.id/DetailOpac.aspx?id=448255.

Makarao; Mohammad Taufik. Pokok-pokok Hukum Acara Perdata. Rineka Cipta, 2009. 
Mardani. Hukum Acara Perdata Peradilan Agama Dan Mahkamah Syar'Iyah. Jakarta: Sinar Grafika, 2010.

Markoni and Elfrida R Gultom. Hukum Acara Perdata. Jakarta: Mitra Wacana Media, 2014.

Mertokusumo, Sudikno. Hukum acara perdata Indonesia. Yogyakarta: Universitas Atma Jaya Yogyakarta, 2010.

Moh. Mahfud M. D. Politik hukum di Indonesia. Jakarta: Rajawali Pers, 2011.

Noor, Muhammad. "Penyelesaian Gugatan Sederhana di Pengadilan (Small Claim Court) Berdasarkan Peraturan Mahkamah Agung Nomor 2 Tahun 2015." YUDISIA : Jurnal Pemikiran Hukum dan Hukum Islam 11, no. 1 (June 5, 2020): 53-66. https://doi.org/10.21043/yudisia.v11i1.6692.

Nurhalizah, Ayu Rahayu. "Problematika Gugatan Sederhana Dalam Tinjauan Peraturan Mahkamah Agung Nomor 2 Tahun 2015 Dan Maslahah Mursalah." Journal of Islamic Business Law 4, no. 2 (August 4, 2020): 1-15.

Riyanto, Benny, and Hapsari Tunjung Sekartaji. "Pemberdayaan Gugatan Sederhana Perkara Perdata Guna Mewujudkan Penyelenggaraan Peradilan Berdasarkan Asas Sederhana, Cepat Dan Biaya Ringan." Masalah-Masalah Hukum 48, no. 1 (January 30, 2019): 98-110. https://doi.org/10.14710/mmh.48.1.2019.98-110.

Roihan A. Rasyid. Upaya hukum terhadap putusan peradilan agama. Jakarta: Pedoman Ilmu Jaya, 1989.

Saraswati, Putu Sekarwangi. "Kebijakan Hukum Terhadap Penanganan Pandemi Covid-19 di Indonesia." KERTHA WICAKSANA 14, no. 2 (July 23, 2020): 147-52. https://doi.org/10.22225/kw.14.2.1923.147-152.

Septi Wulan Sari. "Penyelesaian Sengketa Melalui Small Claim Court." Ahkam: Jurnal Hukum Islam 4, no. 2 (2016). http://ejournal.iaintulungagung.ac.id/index.php/ahkam/article/view/319.

Setiawan. Aneka masalah hukum dan hukum acara perdata. Bandung: Alumni, 1992.

Soimin. Pembentukan peraturan perundang-undangan negara di Indonesia. Yogyakarta: UII Press, 2010.

Tahmid, Khairuddin. "Legislasi hukum islam persektif tata hukum indonesia." ElIzdiwaj: Indonesian Journal of Civil and Islamic Family Law 1, no. 1 (September 18 , 2020). http://ejournal.radenintan.ac.id/index.php/ElIzdiwaj/article/view/7082.

Tjoneng, Arman. "Gugatan Sederhana Sebagai Terobosan Mahkamah Agung Dalam Menyelesaikan Penumpukan Perkara Di Pengadilan Dan Permasalahannya." Dialogia Iuridica: Jurnal Hukum Bisnis Dan Investasi 8, no. 2 (June 8, 2017): 93-106. https://doi.org/10.28932/di.v8i2.726.

Triwijaya, Ach Faisol, Yaris Adhial Fajrin, and Arif Prasetyo Wibowo. "Quo Vadis: Pancasila Sebagai Jiwa Hukum Indonesia." Jurnal Pendidikan PKN (Pancasila dan Kewarganegaraan) 1, no. 2 (November 2, 2020): 115-29. https://doi.org/10.26418/jppkn.v1i2.41083.

Wahjono, Padmo. Indonesia Negara Berdasarkan Atas Hukum. Jakarta: Ghalia Indonesia, 1983.

Whelan, Christopher J. Small Claims Courts: A Comparative Study. New York: Oxford University Press, 1990. 